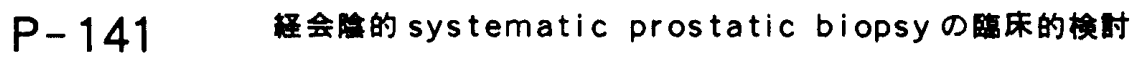

川崎医科大学论尿器科

山本徳則，古川洋二，常政，松木暒和，絹川敬吾，田中啓幹

【目的】経会㓌的systematic prostatic biopsyの烸床的の意義を明らかにする。【対象】1993 年8月より19

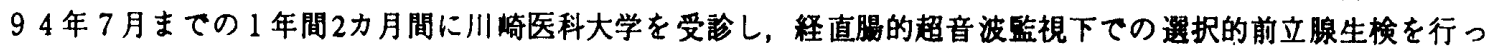

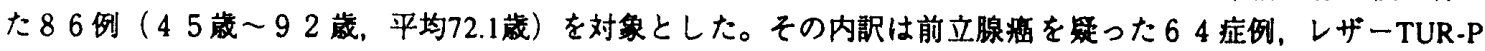
時に潜在痁の否定のため行った 22 症例であった。【方法】選択的前立腺生検は原則として perpheral zoneを 6 力 所特に超音波検査上 central zone にhypoechoic lesionが存在する场合選択的な生検を加えた。【結果】選択的前立 腺生検を行った 86 例中前立腺痹は 23 症例て，その内PSA が3.6ng/ml以下の 4 症例を含んていた。DRE、

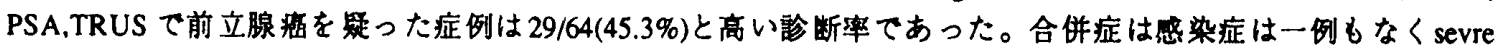
macrohematuria 1 例であった。尿道付近に認められたhypoechoic lesion 生険した時生じたものと思われた。【考 察】この方法が前立腺癌の診断上優れているかどうかは前立腺全摘症例で検討する必要があるが，合併症がきわ めて少なく外来レベルで施行可能である約 $30 \%$ 前立腺癌の確診をえることのできるこの方法は醫床的に意義 が高いと思われる。

\begin{tabular}{|l|l|l|l|l|r|}
\hline & \multicolumn{1}{|c|}{ DRE(-) } & $n=41$ & DRE(+) & $n=45$ & \\
\hline PSA & TRUS(-) & TRUS(+) & TRUS(-) & TRUS(+) & \\
\hline$\leqq 3.6$ & $0 / 22$ & $0 / 8$ & $0 / 4$ & $4 / 16(25.0 \%)$ & $4 / 50(8.0 \%)$ \\
\hline $3.6-9.9$ & $1 / 4$ & $2 / 5(40.0 \%)$ & $0 / 1$ & $2 / 2$ & $5 / 12(41.7 \%)$ \\
\hline $10 \leqq$ & $0 / 1$ & - & $1 / 2$ & $20 / 21$ & $20 / 24(83.3 \%)$ \\
\hline Total & $1 / 27(3.7 \%)$ & $2 / 13$ & $1 / 7$ & $26 / 39(66.7 \%)$ & $29 / 86(33.7 \%)$ \\
\hline
\end{tabular}

DRE :直渴嗙

PSA(ng/ml)

:前立.腺特異抗原 TRUS

: 経直腸的超音波断層検䍒:

\section{P-142 経直滕的前立滕エコー下多所生㛟の模时}

東京女子医科大学

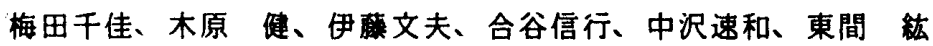

【目的】経直腸前立腺エコー下で前立腺多所生検は、前立腺酃検出のための有効な手段といわれている。 当院における多所生娭結果を検討した。

【対象と方法】1993 年11月加ら1994 年 9 月までに、東京女子医大必尿器科汇おいて経直晹的前立腺 エコー下で sextant biopsyを括てなった 34 例を対象とし、生検前PSA 值、直腸彭、エコー彭断、生 娭結果、生㮥合併症について検討した。

【結果】34例中、前立腺癌は13例で検出された。そのうち、PSA 值（EIKEN）10以下のものは 5 例、

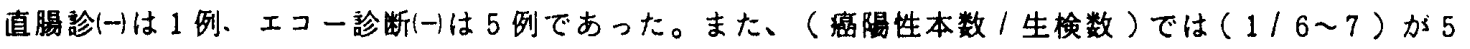
例、（2/6）が 2 例であった。 5 例亿镸延性血尿、血精液、直腸出血をみとめたがいずれも基度であっ た。

【結論】経直腸的前立腺エコー下生検を多所行なうことで、合併症の頻度は增加する傾向がとめられ たがいずれる柽度であり、他所生検は㮴極的に行なうべきと考えられた。 